\title{
Hozzászólás az Egészpályás letámadás a kövérség ellen - Komplex beavatkozásokkal az elhízás visszaszorítására címú közleményhez
}

\author{
Comment on 'Fullback tactics against obesity. Complex interventions \\ to control obesity'
}

\author{
Szerző: Kovács Anna Viktória $\square$ \\ Országos Gyógyszerészeti és Élelmezés-egészségügyi Intézet
}

Beküldve: 2018. 01. 05.

doi: 10.24365/ef.v59i1.223

Kulcsszavak: elhízás; komplex beavatkozás; egészség-magatartás, környezet

Keywords: obesity; complex intervention; health behavior; environment

Az elhízás kialakulásának hátterében kockázati tényezők bonyolult hálózata áll. Ha ezt a komplexitást nem vesszük figyelembe a megelőzés, illetve a kezelés terén, nem leszünk sikeresek, legalábbis hosszú távon biztosan nem. Ez a hozzáállás nélkülözhetetlen mind a beavatkozásokat előkészítő kutatások, mind a beavatkozások és azok értékelése során. ${ }^{1}$ Ha ugyanis rossz kutatási kérdéseket teszünk fel és azokra keressük a válaszokat, nem fogunk olyan összetett népegészségügyi problémákra megfelelő megoldásokat találni, mint az elhízás.

Szerencsére komplex rendszerekkel való munka terén számos jó példa áll előttünk más tudományterületekről, ilyenek például a gazdasági kutatások vagy a klímaváltozás. Emellett a népegészségügy háza táján is látunk sikeres gyakorlatokat összetett problémák megoldására, például a dohányzás viszszaszorítására, ahogy a közlemény is említi.

Az elhízás megelőzése területén számos jó gyakorlat áll rendelkezésre az egyes rizikófaktorok vonatkozásában. Ezek a gyakorlatok általában egy bizonyos kockázati tényezőt céloznak meg, mint például a cukros üdítőitalok fogyasztása vagy a testmozgás hiánya, amelyeket a cikk is említ. Ritkán találkozunk olyan beavatkozással azonban, ami egyszerre több fronton is támad és a teljes életkorspektrumot figyelembe veszi. 2017-ben az Egészségügyi Világszervezet (WHO) lengyel irodája kérésére készítettem egy beszámolót, ami más országok számára is jó példa lehet annak vonatkozásában, hogy hogyan lehet egyszerre több ponton ható intervenciót tervezni. ${ }^{2}$ A riport a Commission on Ending Childhood Obesity ajánlásait ültette át a gyakorlatba, figyelembe véve egy konkrét ország jogi környezetét, kultúráját és lehetőségeit. ${ }^{3}$ Tanulva a lengyel gyakorlatból, első lépésként nélkülözhetetlen, hogy legyen egy elhízásra vonatkozó cselekvési tervünk, hiszen már a szerzők is számos példát hoznak arra, hogy Magyarországon milyen sok intervenció, illetve jogszabály fut jelenleg is, azonban hiányzik a koordináció és egy összehangolt stratégia, ami mind a humán, mind a pénzügyi erőforrások jobb elosztását is szolgálná.

Az elhízás kezelése terén sokkal rosszabb a helyzet. ${ }^{4}$ Ezen a téren sem az infrastruktúra, sem a betegutak, sem a finanszírozás, sem a diagnosztikai, illetve kezelési protokoll vonatkozásában nincs egységes módszertan hazánkban. Nem kell nagyon szégyenkeznünk, ez a jelenség viszonylag általános Európában, illetve világviszonylatban is kevés a jó gyakorlat, amit átvehetnénk. Kezelés terén elsősorban az alapellátásra, illetve gyermekeknél a védőnői 
hálózatra lehetne támaszkodni, ám jelenleg sem a háziorvosok, sem a védőnők nem rendelkeznek a szükséges tudással és képesítésekkel, ami a kezeléshez szükséges lenne. Alapvető lenne legalább a diagnózis felállítása, de az esetek nagy százalékában a viziteknél nem kerül sor a tápláltsági állapot meghatározására, illetve túlsúly esetén az esetleges szövődmények fennállásának vizsgálatára. ${ }^{5} \mathrm{Ha}$ felállításra is kerül a diagnózis, protokollok, illetve egyértelmű betegutak nélkül és a kezeléshez szükséges munkacsoportok vagy centrumok hiányában a sikeresség minimális.

Bár az elhízás gazdasági vonatkozásai már most is jelentősek, tekintettel arra, hogy a legutóbbi adatok szerint az elmúlt negyven évben a gyermekkori túlsúly és elhízás előfordulása tízszeresére nőtt, ${ }^{6}$ a legnagyobb terhet a mostani generáció felnövésekor fogjuk érzékelni, ha mindaddig nem teszünk ellene.

\section{HIVATKOZÁSOK}

\footnotetext{
${ }^{1}$ Rutter H, Savona N, Glonti K, et al. The need for a complex systems model of evidence for public health. Lancet. 2017 Dec 9;390: 2602-4. doi: 10.1016/S0140-6736(17)31267-9.

${ }^{2}$ Reducing childhood obesity in Poland by effective policies. Copenhagen: WHO Regional Office for Europe; 2017. http://www.euro.who.int/_data/assets/pdf_file/0011/350030/Reducing-childhood-obesity-in-Poland_final_WEB.pdf?ua=1 Elérve: 2018.01. 22.

${ }^{3}$ Report of the commission on ending childhood obesity. Geneva: World Health Organization; 2016. http://apps.who.int/iris/bitstream/10665/204176/1/9789241510066_eng.pdf?ua=1 Elérve: 2018. 01. 22. ${ }^{4}$ https://janpa-toolbox.eu/index.php Elérve: 2018. 01. 22.

${ }^{5}$ Kuhle S, Doucette R, Piccinini-Vallis H, et al. Successful childhood obesity management in primary care in Canada: what are the odds? Peer J. 2015;3:e1327.

${ }^{6}$ Abarca-Gómez L, Abdeen ZA, Hamid ZA, et al. Worldwide trends in body-mass index, underweight, overweight, and obesity from 1975 to 2016: a pooled analysis of 2416 population-based measurement studies in 128.9 million children, adolescents, and adults. Lancet. 2017 Oct 11;390:2627-42.
} 